\title{
HDAC6 inhibitor WT161 downregulates growth factor receptors in breast cancer
}

\author{
Teru Hideshima ${ }^{1}$, Ralph Mazitschek ${ }^{2}$, Jun Qi ${ }^{1}$, Naoya Mimura ${ }^{1,5}$, Jen-Chieh Tseng ${ }^{3,6}$, \\ Andrew L. Kung ${ }^{3,4,7}$, James E. Bradner ${ }^{1,8}$ and Kenneth C. Anderson ${ }^{1}$ \\ ${ }^{1}$ Department of Medical Oncology, Dana-Farber Cancer Institute and Harvard Medical School, Boston, MA, USA \\ ${ }^{2}$ Center for Systems Biology, Massachusetts General Hospital, Harvard Medical School, Boston, MA, USA \\ ${ }^{3}$ Lurie Family Imaging Center, Dana-Farber Cancer Institute, Boston, MA, USA \\ ${ }^{4}$ Department of Pediatric Oncology, Dana-Farber Cancer Institute and Children's Hospital Boston, Boston, MA, USA \\ ${ }^{5}$ Department of Hematology, Chiba University Hospital, Chiba, Japan \\ ${ }^{6}$ PerkinElmer Inc., Hopkinton, MA, USA \\ ${ }^{7}$ Memorial Sloan Kettering Cancer Center, New York, NY, USA \\ ${ }^{8}$ Novartis Institutes for BioMedical Research, Cambridge, MA, USA \\ Correspondence to: Kenneth C. Anderson, email: kenneth_anderson@dfci.harvard.edu \\ Keywords: histone deacetylase inhibitor, breast cancer, estrogen receptor, epidermal growth factor receptor, proteasome inhibi- \\ tor
}

Received: March 24, $2017 \quad$ Accepted: June 08, $2017 \quad$ Published: July 05, 2017

Copyright: Hideshima et al. This is an open-access article distributed under the terms of the Creative Commons Attribution License 3.0 (CC BY 3.0), which permits unrestricted use, distribution, and reproduction in any medium, provided the original author and source are credited.

\section{ABSTRACT}

We have shown that WT-161, a histone deacetylase 6 (HDAC6) inhibitor, shows remarkable anti-tumor activity in multiple myeloma (MM) in preclinical models. However, its activity in other type of cancers has not yet been shown. In this study, we further evaluated the biologic sequelae of WT161 in breast cancer cell lines. WT161 triggers apoptotic cell death in MCF7, T47D, BT474, and MDA-MB231 cells, associated with decreased expression of EGFR, HER2, and ERa and downstream signaling. However, HDAC6 knockdown shows that cytotoxicity and destabilization of these receptors triggered by WT161 are not dependent on HDAC6 inhibition. Moreover WT161 analog MAZ1793, which lacks HDAC inhibitory effect, similarly triggers cell line growth inhibition and downregulation of these receptors. We also confirm that WT161 significantly inhibits in vivo MCF7 cell growth, associated with downregulation of ERa, in a murine xenograft model. Finally, WT161 synergistically enhances bortezomibinduced cytotoxicity, even in bortezomib-resistant breast cancer cells. Our results therefore provide the rationale to develop a novel class of therapeutic agents targeting growth pathways central to the pathogenesis of breast cancer.

\section{INTRODUCTION}

Histone proteins are localized in the nuclei of all eukaryotic cells and, as the predominant protein components of chromatin, play a major role in modulating the binding of transcription factors to DNA. The accessibility of expressed genes and the assembly of transcriptional complexes are influenced by posttranslational side-chain acetylation (Kac) of lysine residues on unstructured amino-terminal histone tails. Acetylation of lysine is regulated by the balance of activities of two key classes of enzymes: histone acetyltransferases (HAT) and histone deacetylases (HDAC). Recent studies have shown that HDAC inhibitors are promising anti-tumor agents for various malignancies; consequently, structurally diverse HDAC inhibitors have either been purified from natural sources or developed through synthetic efforts as chemical probes and therapeutic agents.

HDAC6 is a class IIB lysine deacetylase which exerts various biologic activities in different cell types 
[1]. In multiple myeloma (MM), we have shown that HDAC6 knockdown or treatment with the selective small molecule HDAC6 inhibitors tubacin [2], ricolinostat [3], and WT161 [4], synergistically enhances bortezomibinduced cytotoxicity. In breast cancer cells, HDAC6 is a critical component of the invasive apparatus of tumor cells [5], and impacts epithelial organization of HER2-positive breast cancer cells [6]. HDAC6 also deacetylates HMGN2 to regulate STAT5a activity and breast cancer growth [7]. In clinical trials, levels of HDAC6 mRNA expression are a prognostic factor and marker of endocrine responsiveness [8]. Specifically, patients with HDAC6-positive breast cancer have longer progression-free survival and have increased overall survival after tamoxifen treatment, compared to patients with HDAC6-negative tumors [9]. To date, however, the biologic significance of HDAC6 in breast cancer has not been fully elucidated.

In this study, we examined the role of HDAC6 in breast cancer pathogenesis using HDAC6 knockdown and HDAC6-selective inhibitor WT161 [4], in breast cancer cell lines. Since proliferation of breast cancer cells is mediated by transmembrane growth factor receptors and intracellular hormone/steroid receptors including epidermal growth factor receptor (EGFR), human epidermal growth factor receptor 2 (HER2), HER3, KIT, estrogen receptor (ER), and progesterone receptor (PGR), we examined the effects of WT161 on receptor mRNA and protein expression. WT161 downregulated EGFR, HER2, and ER on breast cancer cells, associated with significant tumor growth inhibition both in vitro and in vivo in a xenograft mouse model. Surprisingly, knock-down of HDAC6 did not demonstrate comparable biological effects, suggesting that the anti-proliferative activity of WT161 in breast cancer is not HDAC6 dependent. To explore this further, we prepared a synthetic analogue of WT161, MAZ1793, which lacks HDAC inhibitory activity, and observed comparable downregulation of growth receptors associated with a robust antiproliferative response. In MM, we have demonstrated remarkable anti-proliferative activity of the proteasome inhibitor bortezomib in preclinical models $[10,11]$ and in patients with relapsed-refractory disease [12, 13], leading to its FDA approval. In contrast, the single agent activity of bortezomib in solid tumors including breast cancer is limited. Here we show that WT161 significantly enhances bortezomib-induced cytotoxicity, even in bortezomib-resistant breast cancer cells. Taken together, our data demonstrate that both WT161 and MAZ1793 trigger downregulation of growth factor receptors and growth inhibition in breast cancer cells, providing the preclinical rationale for the development and evaluation of derivatives for clinical evaluation to improve patient outcome in breast cancer.

\section{RESULTS}

\section{WT161 induces cytotoxicity in breast cancer cell lines}

WT161 was synthesized as a novel selective HDAC6 inhibitor (Supplementary Figure 1). Since we have previously shown that HDAC6 inhibitor tubacin selectively induces acetylation of $\alpha$-tubulin [14], we first examined protein acetylation in MCF7 cells induced by WT161, vorinostat (SAHA), and panobinostat (LBH589) using anti-ac-lysine and anti-ac- $\alpha$-tubulin Abs. WT161 strongly increases acetylation of $\alpha$-tubulin, without hyperacetylation of histones. In contrast, SAHA and LBH589 trigger acetylation of histones, with modest acetylation of $\alpha$-tubulin. Since K40-Ac $\alpha$-tubulin is a substrate of HDAC6, this result indicates that WT161 is a more selective inhibitor of HDAC6 than these pharmaceutical and investigational agents (Figure 1A). We next examined the growth inhibitory effect of WT161 in 4 breast cancer cell lines (MCF7, T47D, BT474, MDAMB231). WT161 triggers significant growth inhibition in a dose-dependent fashion. Interestingly, MDA-MB231, a triple-negative cell line, shows the lowest sensitivity to WT161 (Figure 1B). To compare the growth inhibitory effect of WT161 with other HDAC inhibitors, we cultured MCF7 cells in the presence of SAHA (Figure 1C) and LBH589 (Figure 1D), which have shown potent cytotoxicity against $\mathrm{MM}$ cells at low $\mu \mathrm{M}$ and low $\mathrm{nM}$ range, respectively $[15,16]$. MCF7 cells are relatively resistant to these non-selective HDAC inhibitors, but are sensitive to WT161.

\section{WT161 induces caspase cleavage and apoptosis, associated with XIAP downregulation}

We next examined mechanisms of action of WT161induced cytotoxicity in MCF7 cells, a caspase-3 deficient cell line. Consistent with cytotoxicity profiling, WT161 strongly triggers caspase-7 and PARP cleavage in a dosedependent fashion; in contrast, no caspase-7 or PARP cleavage is induced by SAHA, MS275, or LBH589 treatment (Figure 2A). A previous study has shown that $\mathrm{X}$-linked inhibitor of apoptosis protein (XIAP) mediates anti-apoptosis in breast cancer cells [17]. We show that WT161 also downregulates XIAP expression in a doseand time-dependent fashion (Figure 2B), whereas SAHA does not. (Figure 2C). Since a previous report shows

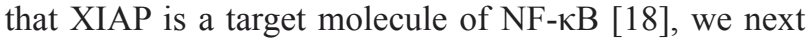
examined whether WT161 inhibited NF-кB activity. Neither WT161 nor other HDAC inhibitors targeted NF$\kappa \mathrm{B}$ (Figure 2D). To confirm the role of caspase activation in WT161-induced cytotoxicity, we cultured MCF7 cells with WT161 in the presence of pan-caspase inhibitor 
Z-VAD-FMK. Cytotoxicity is significantly blocked by Z-VAD-FMK (Figure 2E), indicating that WT161-induced cytotoxicity is, at least in part, mediated via caspasedependent apoptosis.

\section{HDAC6 inhibition does not solely account for} WT161-induced cytotoxicity

To examine the significance of HDAC6 inhibition in breast cancer cell growth, we transiently transfected HDAC6 siRNA into MCF7 cells. HDAC6 expression was almost completely downregulated by HDAC6 siRNA, associated with upregulation of acetylated tubulin (Figure 2F). Surprisingly, no growth inhibitory effect was observed in HDAC6 siRNA transfected MCF7 cells (Figure 2G). These results strongly suggest that HDAC6 inhibition does not account for WT161-induced cytotoxicity.

\section{WT161 downregulates EGFR and ER $\alpha$ expression}

Previous studies have shown that loss of HDAC6 downregulates EGFR expression in lung cancer cells [19, 20]. We therefore next examined whether WT161 could downregulate EGFR and/or other receptor expression in breast cancer cells. WT161 decreases expression of EGFR and ER $\alpha$ in MCF7 cells in a time-dependent fashion (Figure 3A), without affecting the expression of estrogenrelated receptor (ERR)- $\alpha$ (data not shown). WT161 dosedependent downregulation of EGFR and ER $\alpha$ is also observed in T47D cells. Phospho-ERK, downstream of EGF/EGFR, is downregulated by WT161 treatment, but phospho-Akt/Akt is not altered (Figure 3B). RT-PCR shows that mRNA levels of EGFR, HER2, or ER $\alpha$ in MCF7 cells are not altered by WT161 treatment (Figure 3C). Importantly, we do not observe downregulation of EGFR or ER $\alpha$ in HDAC6 siRNA transfectants (data not
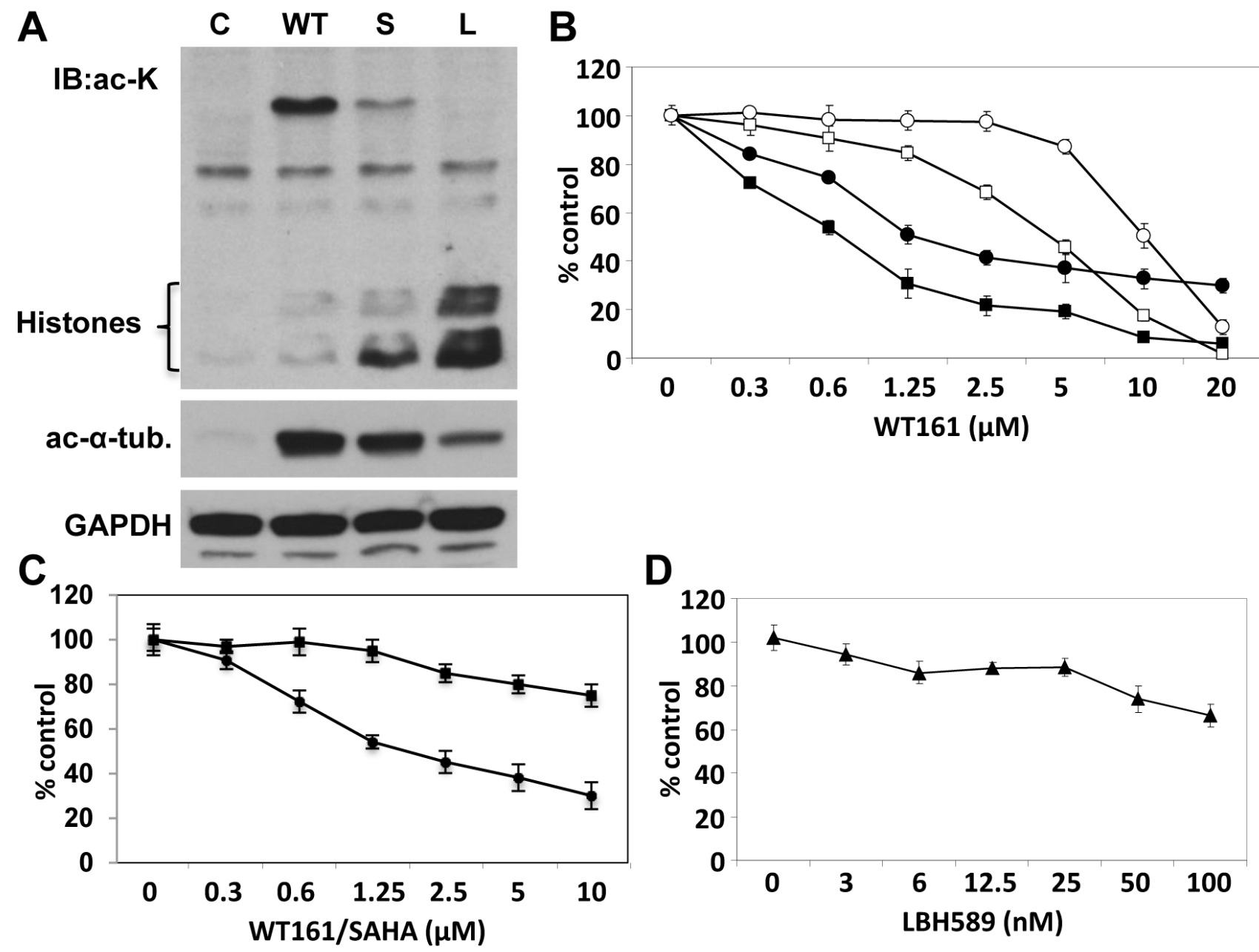

Figure 1: WT161 triggers cytotoxicity in breast cancer cell lines. A. MCF7 cells were cultured in the presence of WT161 (WT, $1 \mu \mathrm{M})$, SAHA (S, $1 \mu \mathrm{M})$, or LBH589 (L, $50 \mathrm{nM}$ ) for $8 \mathrm{~h}$. Whole cell lysates were subjected to immunoblotting using anti-ac-lysine

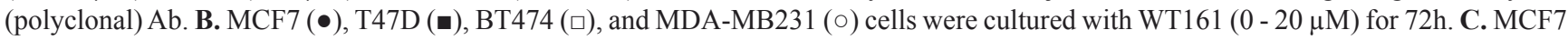

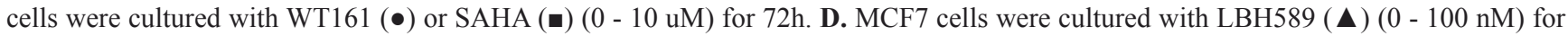
$72 \mathrm{~h}$. Percent survival relative to control was assessed by $72 \mathrm{~h}$ MTT assay. 
shown). Taken together, these results suggest that WT161triggered downregulation of EGFR and ER $\alpha$ in breast cancer cells is due to a post-transcriptional and HDAC6independent event.

\section{HDAC inhibitors differentially downregulate receptor expression}

We next examined whether downregulation of EGFR and ER $\alpha$ was triggered by inhibition of other HDACs, in particular class I HDACs. MCF7 cells were treated with WT161, SAHA, MS275, and LBH589.
WT161 (3 $\mu \mathrm{M})$ markedly downregulates EGFR, HER2, and $\mathrm{ER} \alpha$ at 24h; however, other HDAC inhibitors downregulate only ER $\alpha$ (Figure 4A). Previous studies have shown that HDAC6 inhibition/knockdown hyperacetylates Hsp90 and reduces its chaperone function $[21,22]$. Since these receptors are known Hsp90 client proteins, we hypothesized that receptor downregulation might be due to blockade of Hsp90 via HDAC6 inhibition. We therefore next compared the patterns of receptor downregulation triggered by HDAC inhibitors versus Hsp90 inhibitor 17AAG in MCF7 cells. As expected, 17AAG $(0.5 \mu \mathrm{M})$ significantly destabilizes EGFR, HER2, and $\operatorname{ER} \alpha$, as well as p-ERK and p-Akt. However, no
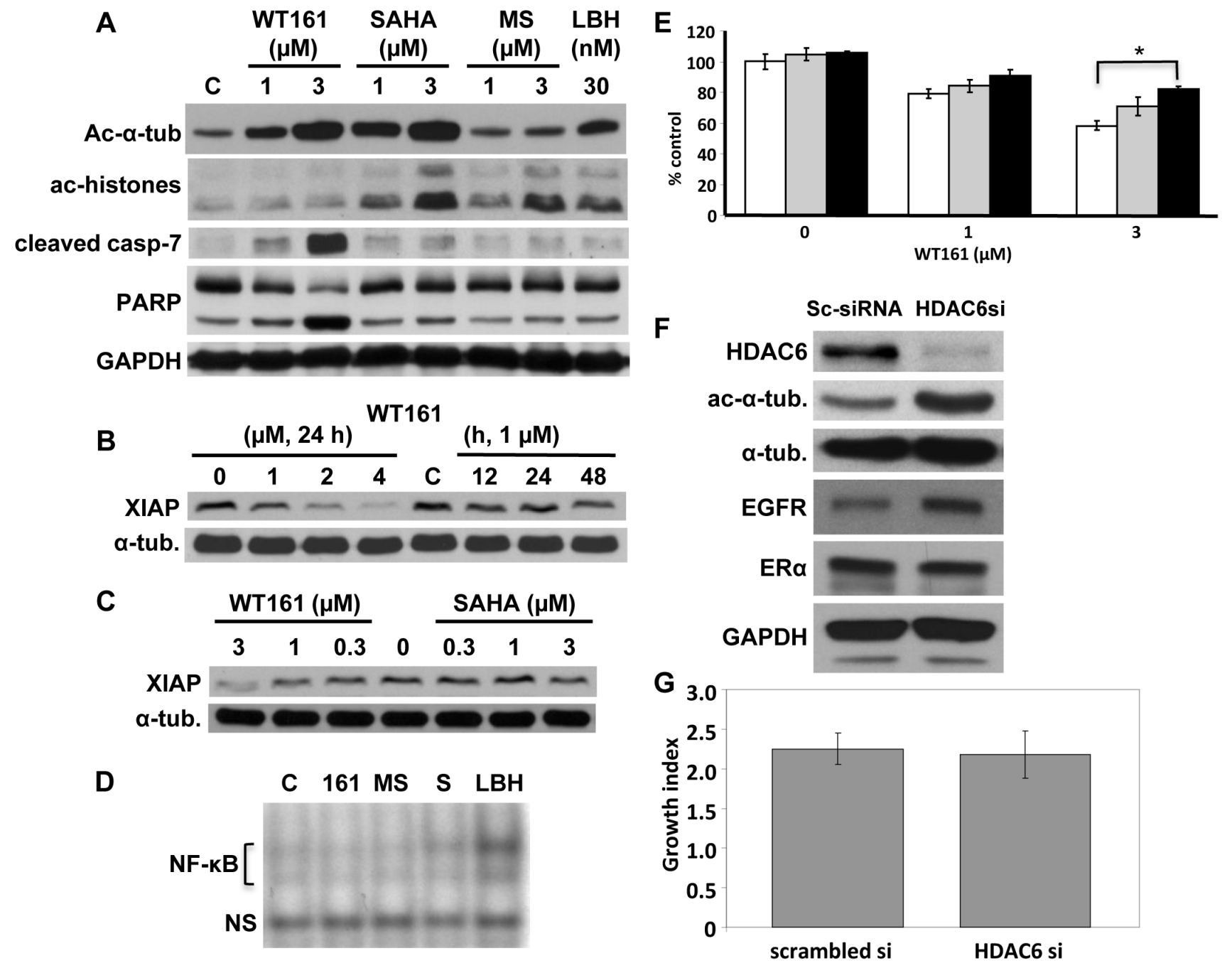

Figure 2: HDAC6 inhibition does not solely account for WT161-induced cytotoxicity. A. MCF7 cells were cultured with WT161 $(1$ and $3 \mu \mathrm{M})$, SAHA (1 and $3 \mu \mathrm{M})$, MS275 (1 and $3 \mu \mathrm{M})$ or LBH589 $(30 \mathrm{nM})$ for 24h. B. MCF7 cells were cultured with WT161 $(1-4 \mu \mathrm{M})$ for $24 \mathrm{~h}$ or with $1 \mu \mathrm{M}$ WT161 for $0 \mathrm{~h}-48 \mathrm{~h}$. C. MCF7 cells were cultured with WT161 $(0.3-3 \mu \mathrm{M})$ or SAHA $(0.3-3 \mu \mathrm{M})$ for $24 \mathrm{~h}$. Whole cell lysates were immunoblotted with indicated Abs. D. MCF7 cells were treated with WT161 (161, $2 \mu \mathrm{M}), \mathrm{MS} 275$ (MS, $2 \mu \mathrm{M})$, SAHA (S, $2 \mu \mathrm{M})$ or LBH589 (LBH, $30 \mathrm{nM})$ for 24h. Nuclear extracts were subjected to EMSA. E. MCF7 cells were cultured for 48h with WT161 $(1$ and $3 \mu \mathrm{M})$, in the absence $(\square)$ or presence of $25 \mu \mathrm{M}(\square)$ and $50 \mu \mathrm{M}(\mathbf{m})$ Z-VAD-FMK. Cell growth was assessed by MTT assay. F. MCF7 cells were transfected with scrambled or HDAC6 siRNA. After 48h culture, whole cell lysates were subjected to immunoblotting using indicated Abs. G. Scrambled- or HDAC6 siRNA-transfected MCF7 cells were cultured for 72h, and cell growth was assessed by MTT assay. *; $p<0.01$. 
common pattern of receptor downregulation is induced by HDAC inhibitors. For example, WT161 $(1 \mu \mathrm{M})$ almost completely downregulates EGFR and ER $\alpha$, whereas TSA $(0.5 \mu \mathrm{M})$ downregulates HER2 and ER $\alpha$. Importantly, WT161 does not inhibit, but rather increases p-Akt. These results are not correlated with ac- $\alpha$-tubulin or ac-histone H3K9 (Figure 4B), suggesting that downregulation of receptors is unlikely to be caused by modulation of HDAC or Hsp90 function. We further performed a side-by-side comparison of WT161 versus 17AAG in 48h cultures of MCF7 cells. 17AAG $(0.5 \mu \mathrm{M})$ significantly downregulates EGFR, HER2, ER $\alpha$ and p-Akt. Importantly, WT161 (2 $\mu \mathrm{M})$ even more potently abrogated EGFR, HER2, and ER $\alpha$ expression than 17AAG; however, it does not alter p-Akt (Figure 4C). These results further support the view that WT161-induced downregulation of these receptors is independent of Hsp90. Of note, WT161 in combination with 17AAG markedly downregulates EGFR, HER2, and $\mathrm{ER} \alpha$, associated with enhanced cytotoxicity in MCF7 cells (Supplementary Figure 2).

To examine the significance of downregulation of receptor expression on breast cancer cell proliferation, MCF7, T47D, BT474, and MDA-MB231 cells were cultured with EGFR tyrosine kinase inhibitor erlotinib (Figure 4D) or ER antagonist tamoxifen (Figure 4E). Importantly, neither of these single agents triggered a growth inhibitory effect as pronounced as WT161. Similar results were observed using the potent ER $\alpha$ downregulator fulvestrant (Supplementary Figure 3). These results suggest that WT161- induced growth inhibition in breast cancer cells is not due to single receptor inhibition.

Recent studies have shown that CUDC-101, a hybrid small molecule inhibitor targeting EGFR/HER2 and HDACs, shows significant anti-tumor effects in various types of cancer cells [23]. We therefore compared the in vitro activity of WT161 versus CUDC-101 in breast cancer cells. WT161, in a dose dependent fashion, downregulates EGFR, HER2 and ER $\alpha$; however, CUDC-101 (3 $\mu \mathrm{M})$ shows only modest downregulation of EGFR and ER $\alpha$, similar to that observed in cells treated with other HDAC inhibitors (Supplementary Figure 4A). Of note, CUDC101 abrogates EGF-induced phosphorylation (Tyr1068) of EGFR in a dose-dependent fashion, associated with growth inhibition in breast cancer cells; however, WT161 had no effect on p-EGFR (Supplementary Figures 4B and 4C).

\section{WT161-triggered downregulation of EGFR or $E R \alpha$ is independent of caspase activation}

Previous studies have shown that the C-terminus domain of EGFR is a target of caspases and subject to
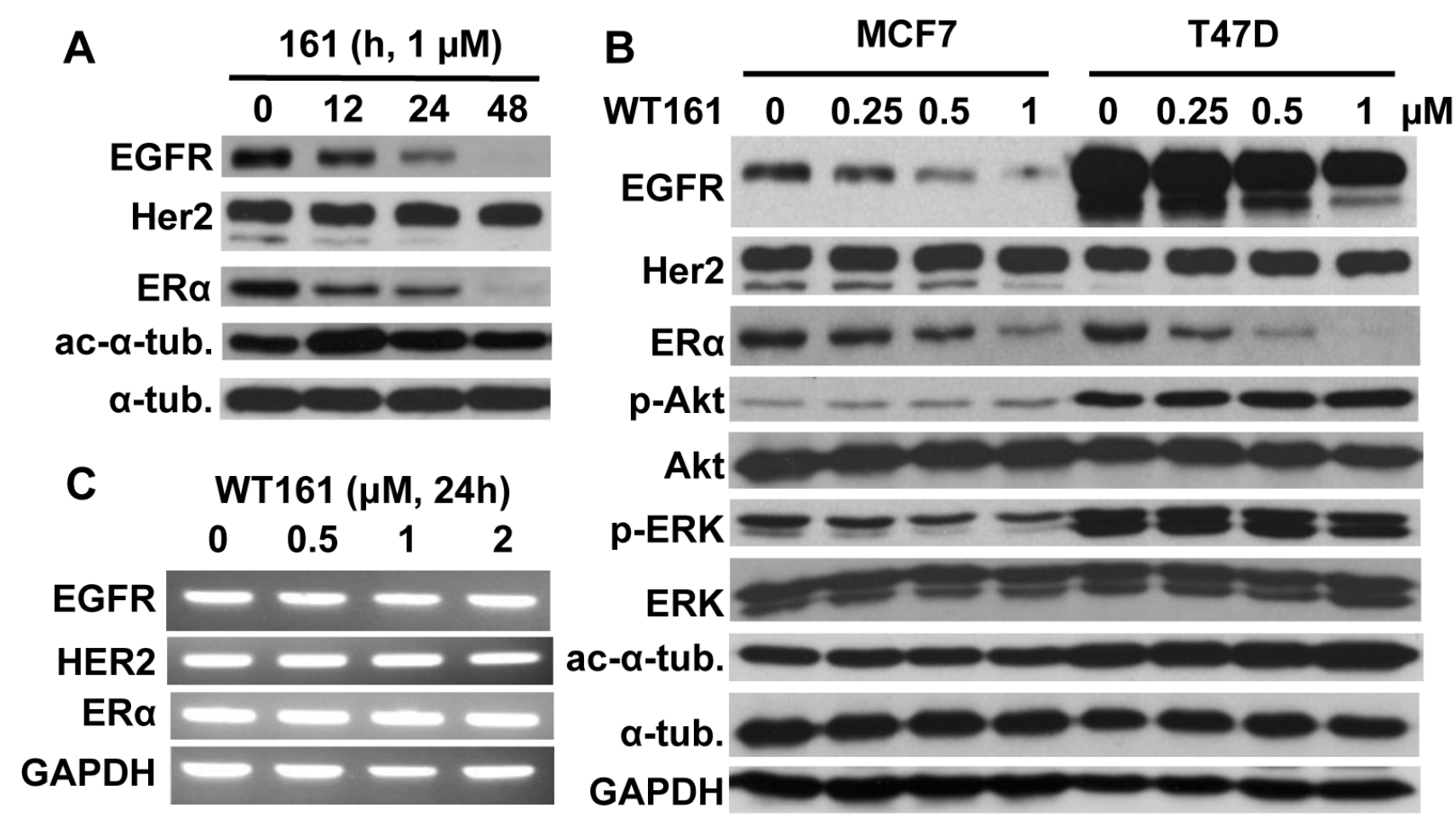

48h culture

Figure 3: WT161 downregulates EGFR and ER $\alpha$ expression. A. MCF7 cells were cultured with WT161 (1 $\mu$ M) for 0 - 48 h. B. MCF7 and T47D cells were cultured with WT161 $(0-1 \mu \mathrm{M})$ for $48 \mathrm{~h}$. Whole cell lysates were subjected to immunoblotting with indicated Abs. C. MCF7 cells were cultured with WT161 $(0-2 \mu \mathrm{M})$ for $24 \mathrm{~h}$. Total RNAs were extracted and subjected to PCR. 
degradation during apoptosis [24]. Since WT161 induces caspase/PARP cleavage followed by apoptosis, we next examined whether downregulation of EGFR was due to caspase activation. WT161 significantly triggers caspase/ PARP cleavage, which is completely abrogated by Z-VADFMK. However, WT161-induced downregulation of EGFR and ER $\alpha$ are not altered in the presence of Z-VADFMK, indicating that EGFR and ER are not substrates of caspases (Figure 4F).

\section{WT161 inhibits MCF-7 tumor growth in a mouse xenograft model}

We next examined the anti-tumor effect of WT161 in an MCF-7 mouse xenograft model. Mice with established tumors were treated with either vehicle control or WT161 at $80 \mathrm{mg} / \mathrm{kg} / \mathrm{day}$, i.p. for 3 weeks. As shown in Figure
5A, WT161 significantly inhibits the growth of MCF-7 xenografts $(p=0.035)$. Since ER $\alpha$ is the most sensitive to WT161 treatment and MCF-7 cells are responsive to $\mathrm{ER} \alpha$ inhibitors (tamoxifen and fulvestrant), we performed immunohistochemical analyses for $\operatorname{ER} \alpha$ expression and TUNEL staining on tumors excised from control and WT161-treated animals. Consistent with the findings above, ER $\alpha$ is markedly decreased in tumors treated with WT161 (Figure 5B). WT161-treated tumors also have increased TUNEL staining (Figure 5B), indicating increased tumor cell death.

\section{WT161 enhances bortezomib-induced cytotoxicity}

Bortezomib demonstrates remarkable clinical activity in MM; however, its activity as a single agent in breast cancer is limited. Moreover, compared to MM cell line RPMI8226, breast cancer cells are relatively
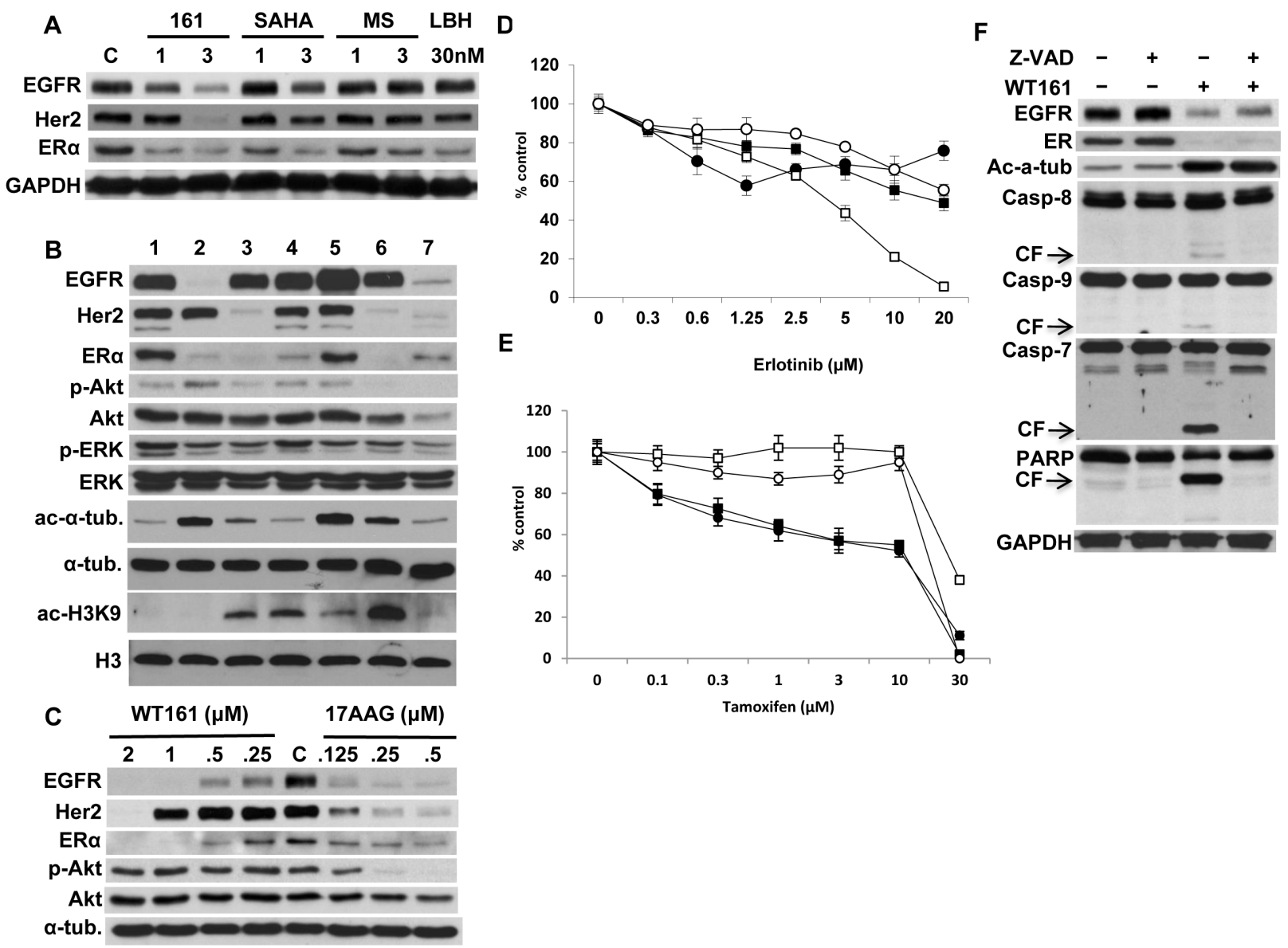

Figure 4: HDAC inhibitors differentially downregulate receptor expression. A. MCF7 cells were cultured with WT161 (1 and $3 \mu \mathrm{M})$, SAHA (1 and $3 \mu \mathrm{M})$, MS275 $(1$ and $3 \mu \mathrm{M})$ or LBH589 $(30 \mathrm{nM})$ for $24 \mathrm{~h}$. B. MCF7 cells were cultured with HDAC inhibitors for 48h. Lanes indicate; 1, DMSO control; 2, WT161 $(1 \mu \mathrm{M}) ; 3$, trichostatin A (TSA, $0.5 \mu \mathrm{M}) ; 4$, MS275 (2.5 $\mu \mathrm{M}) ; 5$, SAHA (1 $\mu \mathrm{M})$; 6 , LBH589 $(50 \mathrm{nM}) ; 7$, 17AAG $(0.5 \mu \mathrm{M})$. C. MCF7 cells were cultured with WT161 $(0.25-2 \mu \mathrm{M})$ or 17AAG $(0.125-0.5 \mu \mathrm{M})$ for $48 \mathrm{~h}$.

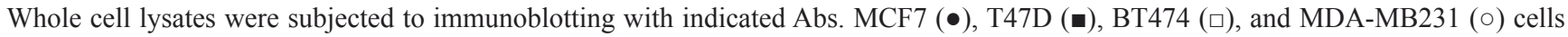
were cultured with erlotinib D. or tamoxifen $\mathbf{E}$. for $72 \mathrm{~h}$, and cell growth was assessed by MTT assay. F. MCF7 cells were cultured with WT161 $(2 \mu \mathrm{M})$, in the absence or presence of Z-VAD-FMK $(50 \mu \mathrm{M})$ for $24 \mathrm{~h}$. Whole cell lysates were subjected to immunoblotting with indicated Abs. 


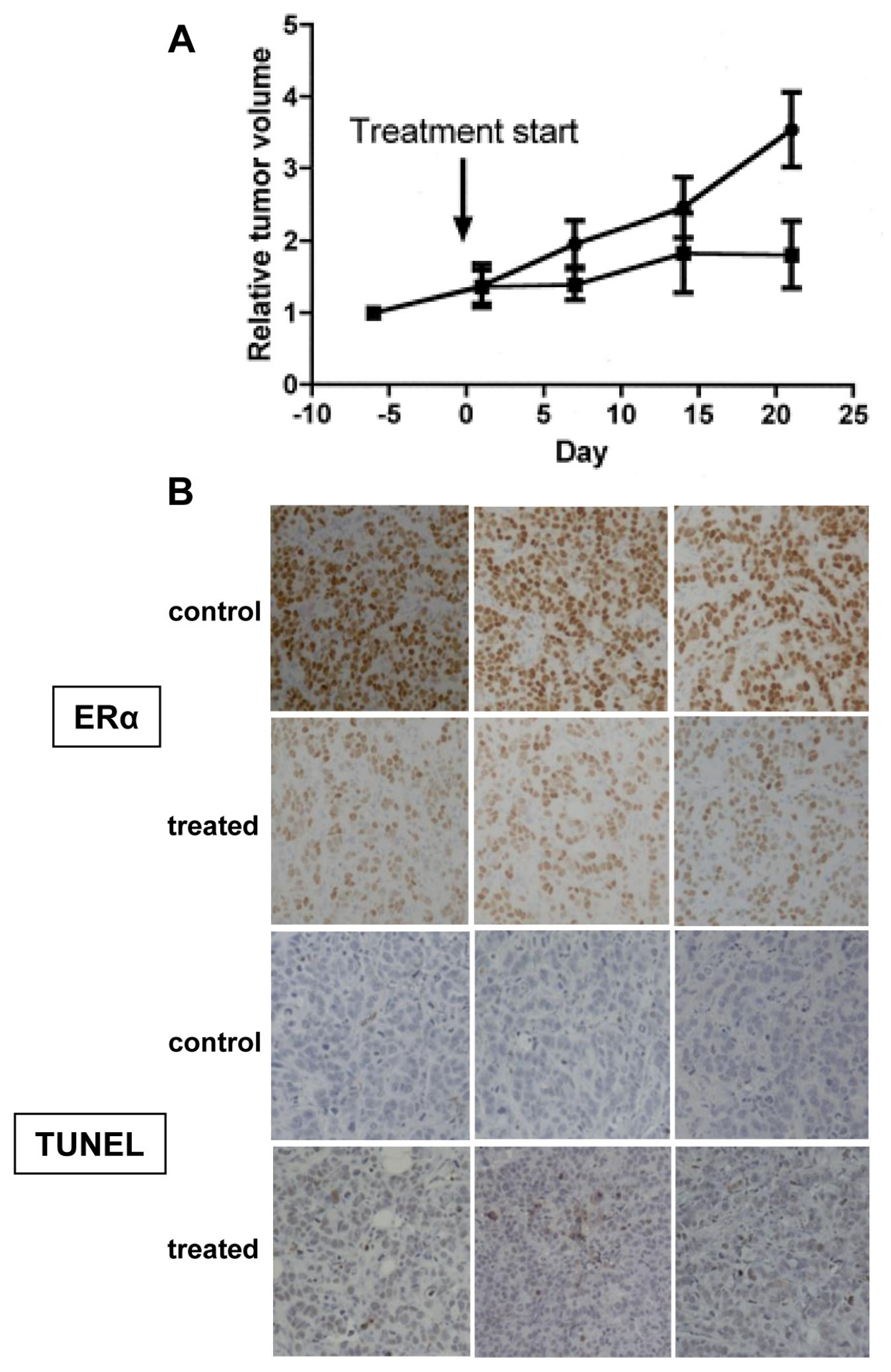

Figure 5: Anti-tumor efficacy of WT161 in MCF7 xenograft tumors. A. Mice with established MCF7 xenograft tumors were assigned into cohorts receiving either daily intraperitoneal WT161 $80 \mathrm{mg} / \mathrm{kg}(n=7, \boldsymbol{\bullet})$ or vehicle control $(n=7, \bullet)$ and relative tumor volume was calculated over time. B. After 3-week treatment, tumors harvested from mice were subjected to IHC analysis. Representative results (ER and TUNEL) from each cohort (control and WT161-treated) are shown. 
resistant to bortezomib treatment. Specifically, MCF7 cells are resistant to treatment with bortezomib (Figure 6A) and other proteasome inhibitors including MG132 (Supplementary Figure 5) and lactacystin (data not shown). Since we have shown that HDAC6 selective inhibitor tubacin significantly enhances bortezomibinduced cytotoxicity in MM cell lines and patient MM cells [14], we examined whether WT161 or other HDAC inhibitors similarly enhanced anti-tumor activity of bortezomib in breast cancer cells. WT161 synergistically $(\mathrm{CI}=0.85)$ enhances bortezomib-induced MCF7 cytotoxicity, whereas SAHA and MS275 show only a modest additive cytotoxic effect (Figure 6B). Similar results with WT161 are observed in BT474 cells (Figure 6C).

Since the growth inhibitory effect of WT161 as a single agent is independent of HDAC6, we next examined whether HDAC6 knockdown enhanced bortezomibinduced cytotoxicity. Interestingly, knockdown of HDAC6 triggers only modest increases in bortezomib-induced cytotoxicity in MCF7 cells (Figure 6D). We therefore further examined the molecular mechanisms whereby WT161 enhances bortezomib-induced cytotoxicity. As shown in Supplementary Figure 6A, bortezomib induces modest cleavage of caspase/PARP which is enhanced by WT161, suggesting that combination treatment enhances apoptotic cell death. Previous studies have shown that HDAC6 plays a crucial role in aggresome formation, in which ubiquitinated-protein aggregates are processed through autophagy [25]. Moreover, inhibition of proteasomal degradation enhances aggresomal (autophagic) protein degradation, thereby preventing accumulation of unfolded/misfolded proteins [26]. Indeed, bortezomib triggers significant autophagic response in MCF7 cells, evidenced by LC3 staining, which is almost completely blocked by WT161 (Supplementary Figure $6 \mathrm{~B}$ ). These results further suggest that combined bortezomib with WT161 treatment induces unfolded protein responses (UPR) in MCF7 cells. Importantly, endoplasmic reticulum stress sensor proteins (IRE1 $\alpha$ and PERK) are downregulated by WT161, but not by SAHA, treatment (Supplementary Figure 7). Since inhibition of the UPR by inhibiting IRE1 $\alpha$ enhances cytotoxicity induced by proteasome inhibitors [27], these data suggest another mechanism whereby WT161 enhances bortezomib-induced cytotoxicity in breast cancer cells. Taken together, these results suggest that single agent anti-tumor activity of WT161 is HDAC6-independent. Importantly, WT161 with bortezomib overcomes bortezomib resistance in breast cancer cells; and HDAC6 inhibition by WT161 can enhance bortezomib-induced cytotoxicity by inhibiting both aggresome/autophagy pathway and UPR in breast cancer cells.
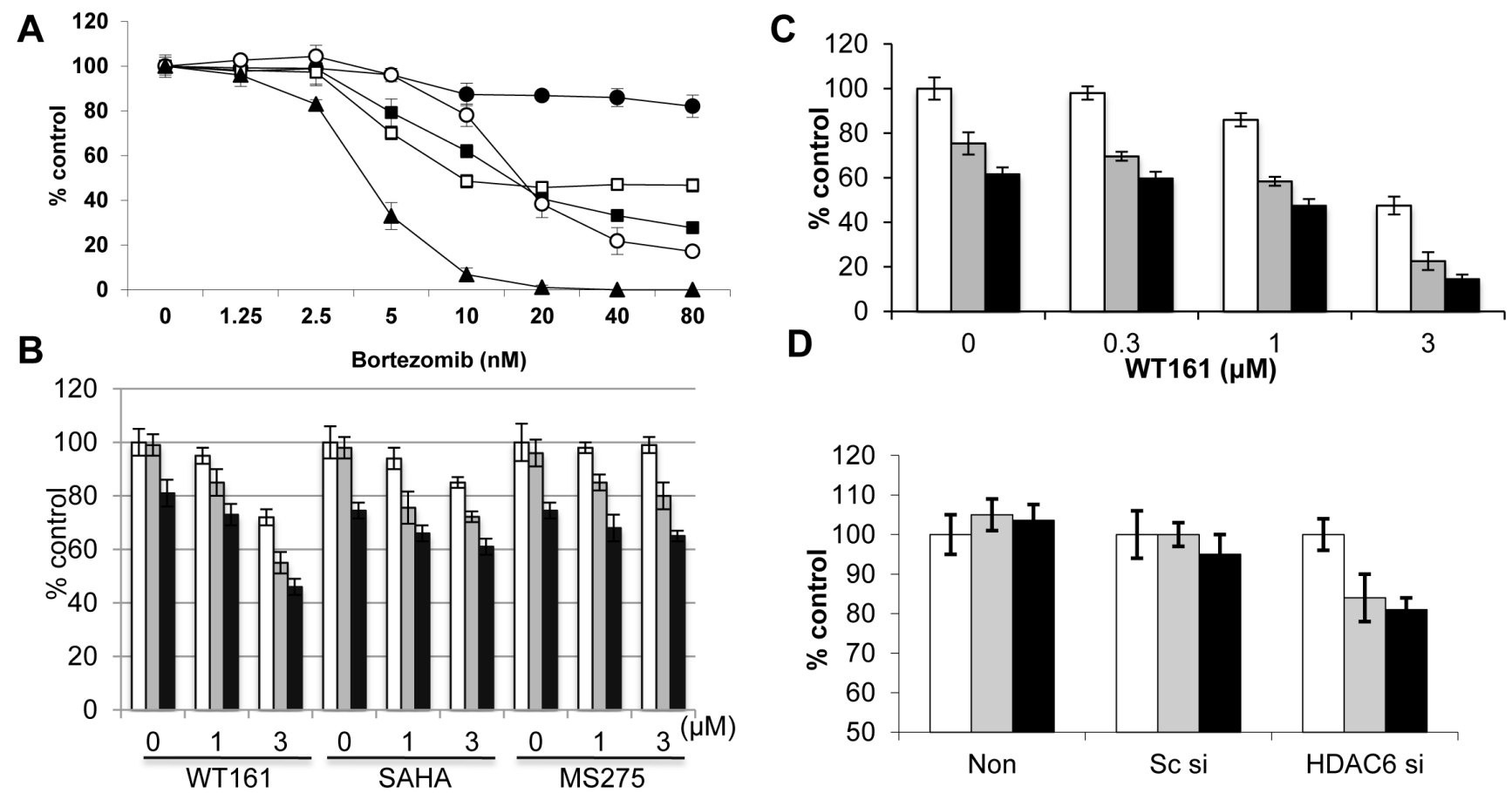

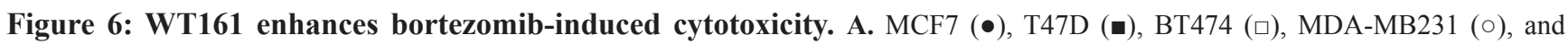
RPMI8226 ( $\Delta)$ cells were cultured with bortezomib (1.25 - $80 \mathrm{nM})$ for 48h. B. MCF7 cells were cultured with WT161, SAHA, or MS275

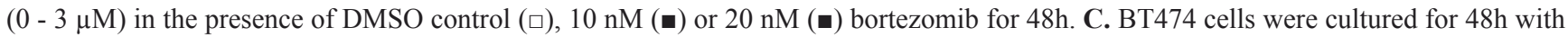
WT161 $(0.3-3 \mu \mathrm{M})$ in the presence of DMSO control $(\square)$, and $5 \mathrm{nM}(\varpi)$ or $10 \mathrm{nM}(\mathbf{\square})$ bortezomib. D. MCF7 cells were transfected with scrambled siRNA (Sc si) or HDAC6 siRNA (HDAC6 si). Cells were then cultured in the presence of DMSO control ( $\square$ ), and $10 \mathrm{nM} \mathrm{(} \square$ ) or $20 \mathrm{nM}(\mathbf{m})$ bortezomib for $48 \mathrm{~h}$. In all cases, cell growth was assessed by MTT assay and compared with control. 
WT161 analog MAZ1793, which lacks HDAC inhibitory activity, induces significant growth inhibition

To precisely define the structure-function relationship between WT161 and the downregulation of growth factors in breast cancer, we prepared a synthetic WT161 analogue MAZ1793, which lacks the zincchelating hydroxamate required for HDAC inhibitory activity (Figure 7A). Similar to WT161, MAZ1793 has significant growth inhibitory effect in MCF7 and T47D cells (Figure 7B). Importantly, this growth inhibition is associated with downregulation of EGFR, Her2, ER $\alpha$ and IRE1 $\alpha$; however, no upregulated acetylation of histones or ac- $\alpha$-tubulin was recognized. These results further confirm that both WT161- and MAZ1793-induced cytotoxicity in breast cancer cells is independent of HDAC inhibition. WT161, but nor MAZ 1793, inhibited bortezomib-induced upregulation of LC3-II, as assessed by immunoblotting which is more quantitative than immunocytochemistry (Supplementary Figure 8).

\section{DISCUSSION}

Chemotherapeutic agents including anthracyclines and taxanes have been combined with targeted therapeutics such as trastuzumab and tamoxifen to improve outcome in subsets of breast cancers. HDAC inhibitors SAHA (vorinostat) [28, 29] and LBH589 (panobinostat) [30], which block class I/II HDACs associated with growth arrest and/or apoptosis, are under evaluation in clinical trials in cancer. HDAC6, a class IIB deacetylase, is a multifunctional, cytosolic protein deacetylase which primarily targets $\alpha$-tubulin [31]. It plays a key role in aggresomal protein degradation, in which aggregated proteins are processed through autophagy [25]. Recent studies have examined the biologic role of HDAC6 in cancer cells, including breast cancer [32, 33]. However, many HDAC inhibitors block class I and class II HDACs, with only weak inhibitory effect against class IIB HDAC including HDAC6. In this study, we used HDAC6 knockdown and the novel potent and highly selective HDAC6 inhibitor WT161 to characterize the effect of HDAC6 inhibition in breast cancer cells.

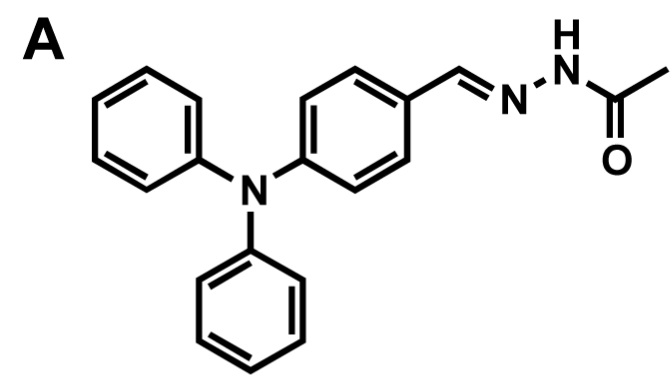

B

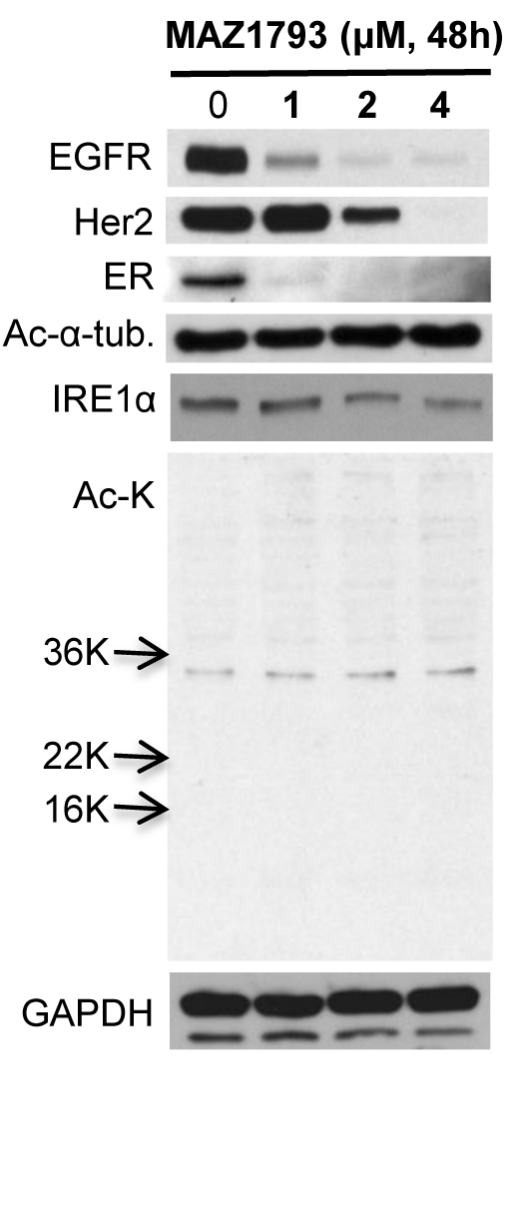

Figure 7: MAZ1793 induces growth inhibition in breast cancer cells. A. Chemical structure of MAZ1793 is demonstrated. B. MCF cells were cultured with MAZ1793 $(1-4 \mu \mathrm{M})$ for $48 \mathrm{~h}$. Whole cell lysates were subjected to Immunoblotting using indicated Abs. C. MCF7 and T47D cells were cultured with MAZ1793 for 72h. Cell growth was assessed by MTT assay and compared with control. 
We first examined the effect of WT161 on proliferation of breast cancer cells. Although growth of all cell lines was inhibited by WT161 treatment, BT474 (triple-positive) and MDA-MB231 (triple-negative) cells are less sensitive than T47D and MCF7 cells. Importantly, the growth inhibitory effect of WT161 is more potent than other pan-HDAC inhibitors including SAHA and LBH589. This cytotoxicity was associated with caspase/ PARP cleavage and is completely blocked by Z-VADFMK, suggesting that WT-161 triggers apoptotic cell death. We also observed that WT161 downregulates IAP family member protein XIAP, which protects cells against apoptosis [34, 35]. Specifically, we observed significant cleavage of caspase-7 and PARP triggered by WT161 treatment, consistent with a previous study showing that XIAP primarily blocks caspase-7 [36]. Moreover, transcriptional regulation of XIAP by NF$\kappa \mathrm{B}$ varies depending on cell type [18, 37]; in our study, no NF- $\kappa \mathrm{B}$ inhibition by WT161 is recognized, suggesting that WT161-triggered XIAP downregulation occurs independently of NF- $\kappa \mathrm{B}$ activity. Importantly, we determined whether WT161-induced cell growth inhibition is due to specific HDAC6 blockade using HDAC6 siRNA knockdown. Surprisingly, no growth inhibitory effect is observed in HDAC6 knockdown cells, indicating that HDAC6 inhibition does not account for WT161-induced cytotoxicity.

Signaling cascades triggered by growth factors/ hormones and their receptors mediate growth and progression of breast cancer cells. Since MDA-MB231 breast cancer cell line is triple-negative and relatively resistant to WT161 treatment, we determined whether WT161 alters expression of growth factor/hormone receptors. Indeed, WT161 markedly downregulates EGFR, HER2, and ER $\alpha$ expression. Previous studies have shown that HDAC6 knockdown inhibits EGFR expression in A549 lung cancer cell line, without affecting their growth [19]. Importantly, HDAC6 is associated with the endosomal compartments and controls EGFR trafficking and degradation [20]. Here we observed downregulation of EGFR induced by WT161, but not by other HDAC inhibitors TSA and SAHA that also inhibit HDAC6. Moreover, we did not observe downregulation of EGFR in HDAC6 knockdown cells, indicating that WT161-triggered EGFR downregulation is independent of HDAC6 inhibition. Since WT161 triggers caspasedependent apoptosis and prior reports show that decreased EGFR may be mediated by activation of caspases [38], we also assessed the role of caspases in WT161triggered modulation of receptor expression. Our results indicate that EGFR is not a substrate of caspases, since Z-VAD-FMK completely abrogates caspase-7 and PARP cleavage, but does not block WT161-induced EGFR downregulation.

Previous studies have shown that HDAC inhibitors downregulate ER $\alpha$ expression in different models [39,
40]. In our study, ER $\alpha$ downregulation is the most potent effect of WT161 treatment, evidenced both in vitro and in vivo in a mouse MCF7 xenograft model. Similar to EGFR expression, we did not observe downregulation of ER $\alpha$ in HDAC6-knockdown cells. Our results are in contrast to previous studies showing that HDAC6 deacetylates Hsp90 and regulates its molecular chaperone function [21, 41]. Since EGFR, HER2, and ER $\alpha$ are known client proteins of Hsp90, it is possible that inhibition of HDAC6 downregulates expression of these receptors via Hsp90 inhibition. However, in our study hyperacetylation of Hsp90 and downregulation of p-Akt, hallmarks of Hsp90 inhibition, are not induced by WT161 treatment. Our results therefore suggest, in contrast to other HDAC inhibitors, that WT161-triggered ER $\alpha$ downregulation is independent of inhibition of HDAC6 or Hsp90.

The impact of downregulation of EGFR and ER $\alpha$ on cell growth was next studied using small molecule inhibitors, erlotinib and tamoxifen, respectively. Erlotinib did not inhibit growth; however, MCF7 and T47D cells, which are sensitive to WT161, were also sensitive to tamoxifen treatment. Similar results were observed with fulvestrant treatment. These results suggest that downregulation of either EGFR or ER $\alpha$ alone cannot solely account for WT161-induced growth inhibition in breast cancer cells. Since we observed downregulation of EGFR, HER2, and ER $\alpha$ induced by Hsp90 inhibitor 17AAG, we also examined whether 17AAG enhanced downregulation of these receptors is triggered by WT161. The combination of WT161 with 17AAG markedly decreases receptor expression associated with enhanced cytotoxicity, providing the rationale to combine WT161 with Hsp90 inhibitors.

The aggresomal protein degradation pathway is an alternative to the proteasome cascade for degradation of polyubiquitinated misfolded/unfolded proteins [42]. Importantly, HDAC6 has an essential role in aggresome formation, since it can bind both polyubiquitinated proteins and dynein motors, thereby acting to recruit protein cargo to dynein motors for transport to aggresomes [25]. We have previously shown that HDAC6 inhibitor tubacin enhances bortezomib-induced apoptosis in MM cells, without toxicity in normal cells [3, 4, 14]. Others have also shown enhanced cytotoxicity of proteasome inhibitors in combination with HDAC inhibitors in multiple cancer types in both preclinical and clinical studies [43-47]. For example, non selective-HDAC inhibitor vorinostat potentiates cytotoxicity of carfilzomib in human diffuse large B-cell lymphoma cells both in vitro and in vivo [48]. To date, HDAC inhibitors utilized in prior studies, including borinostat and panobinostat, are broad class I/II HDAC inhibitors; therefore, whether HDAC6 inhibition solely accounts for enhancing cytotoxicity of proteasome inhibitors remains unclear. In this study, we therefore examined whether WT161, a more potent and selective HDAC6 inhibitor, enhances bortezomib-induced 
cytotoxicity in breast cancer cells. We found that breast cancer cells are more resistant to bortezomib than MM cells. Importantly, WT161 synergistically augments bortezomib-induced breast cancer cytotoxicity. In MM, we have shown that knockdown or blockade of Hsp27 restores sensitivity to bortezomib treatment [49]; conversely, Hsp27 overexpression inhibits doxorubicin-induced apoptosis in breast cancer cells [50]. Moreover, Hsp27 is required for sex steroid receptor (ie, ER $\alpha$ ) localization and functioning at the plasma membrane [51]. In preliminary studies, we observed that Hsp27 is highly expressed in MCF7 cells; however, Hsp27 protein expression was not downregulated by WT161 treatment. Ongoing studies are examining whether phosphorylation and acetylation of Hsp27 is modulated by WT161 treatment.

We demonstrated that WT161, in contrast to HDAC inhibitors vorinostat and panobinostat, blocks bortezomib-induced LC3 expression. These results suggest that proteasome inhibition with bortezomib in breast cancer cells induces compensatory aggresomal protein degradation which can be blocked by WT161 via HDAC6 inhibition, thereby triggering cell stress followed by apoptotic cell death. Since previous studies have also shown that chronic bortezomib exposure causes a reduction of ER $\alpha$ associated with decreased ER $\alpha$ mRNA level in breast cancer cell lines [52], we also examined whether bortezomib could enhance WT161-induced ER $\alpha$ downregulation. No enhanced effect of combination therapy on ER $\alpha$ expression was observed.

These studies have defined a novel anti-cancer mechanism of a new class of small-molecule chemical probes. WT161 and its chemical derivative MAZ1793 induce a decetylase-independent anti-proliferative effect on breast cancer cells, associated with downregulation of EGFR, Her2, and ER $\alpha$. Based on the compelling activity observed in these model studies, we have initiated research directed at the identification of the discrete biochemical target of these agents, which may account for the observed selective destabilization of these critical growth regulatory proteins in breast and ovarian cancer. Furthermore, the observed downregulation of EGFR suggests potential therapeutic application more broadly in cancer, including adenocarcinoma of the lung and glioblastoma multiforme. Our data therefore establish a compelling rationale to develop this class of agents for human clinical investigation, and further mechanistic and translational studies in additional tumor models are ongoing.

\section{MATERIALS AND METHODS}

\section{Cells}

MCF7, T47D, MDA-MB231, and BT474 human breast cancer cell lines, as well as RPMI8229 human MM cell lines, were obtained from American Type Culture Collection (Manassas, VA). The cells were cultured in DMEM (Mediatech Inc., Manassas, VA) or RPMI1640 (Mediatech Inc., Manassas, VA) supplemented with FBS (10\%), penicillin, streptomycin, and glutamine (Invitrogen, Auckland, New Zealand).

\section{Reagents}

WT161 (C27H30N4O3, MW $=458.55$, Supplementary Figure 1) was synthesized by Dr. Bradner's laboratory. MAZ1793 (Figure 7) was generated by Dr. Mazitschek's laboratory. MS275 (entinostat), suberoylanilide hydroxamic acid (SAHA, vorinostat), LBH589 (panobinostat), CUDC-101, tamoxifen, fulvestrant and bortezomib were purchased from Selleck Chemicals (Houston, TX). Erlotinib was purified from discarded patient tablets. MG132 and trichostatin A (TSA) were obtained from Sigma (St. Louis, MO). Z-VAD-FMK and 17-demethoxygeldanamycin (17-AAG) were purchased from EMD Chemicals (San Diego, CA). Epidermal growth factor was obtained from R\&D Systems (Minneapolis, MN).

\section{Cytotoxicity assay}

Cell growth was assessed by measuring 3-(4,5-dimethylthiazol-2-yl)-2,5-diphenyl tetrazolium bromide (MTT) dye absorbance, as described previously [53]. Briefly, breast cancer cells were harvested using $0.05 \%$ trypsin-EDTA (Invitrogen) and distributed into 96-well plates $(10,000-20,000$ cells/well) $24 \mathrm{~h}$ prior to treatment. All experiments were performed three times in quadruplicate. The experiments were carried out three times, and the average \pm SD are demonstrated in Figures.

\section{Immunoblotting}

Cells cultured with WT161 and/or HDAC inhibitors were harvested; washed; and lysed using lysis buffer: $50 \mathrm{mM}$ Tris- $\mathrm{HCl}$ (pH 7.4), $150 \mathrm{mM} \mathrm{NaCl}, 1 \% \mathrm{NP}-40,5$ mM EDTA, $5 \mathrm{mM} \mathrm{NaF}, 1 \mathrm{mM}$ Na3VO4, $1 \mathrm{mM}$ PMSF, $5 \mu \mathrm{g} / \mathrm{ml}$ leupeptine, and $5 \mu \mathrm{g} / \mathrm{ml}$ aprotinin. Whole cell lysates were subjected to SDS-PAGE, transferred to nitrocellulose membrane (Bio-Rad Laboratories, Hercules, $\mathrm{CA}$ ), and immunoblotted with specific Abs, as previously described [53]. Antibodies used were anti-acetylated (ac)lysine (polyclonal), -ac-lysine (K9), -PARP, -caspase-7, -caspase-8, -caspase-9, -IRE1 $\alpha$, -PERK, -XIAP, survivin, cIAP2, - $\alpha$-tubulin, -GAPDH, -phospho (Tyr1068)-EGF receptor (EGFR), -EGFR, -HER2, -ER $\alpha$, -phospho (Ser473)-Akt, -Akt, -phospho (Thr202/Tyr204)-ERK, -ERK, -LC3 Abs (Cell Signaling Technology, Danvers, MA). Anti-HDAC6 Ab was purchased from Sigma and Santa Cruz Technology (Santa Cruz, CA), respectively. 
Anti-ac-tubulin monoclonal Ab was obtained from SigmaAldrich (St. Louis, MO). The experiments were carried out at least three times, and representative results are demonstrated in Figures.

\section{Electrophoretic mobility shift analysis (EMSA)}

EMSA was carried out for detection of $\mathrm{NF}-\kappa \mathrm{B}$ activity, as previously described [54]. Briefly, nuclear extracts from MCF7 cells were obtained using "Nuclear Extraction $\mathrm{Kit}^{\mathbb{\circledR}}{ }^{\mathbb{2}}$ (Panomics, Fremont, CA). Doublestranded NF- $\kappa \mathrm{B}$ consensus oligonucleotide probes (Promega, Madison, WI) were end labeled with $\left[\gamma^{32} \mathrm{P}\right]$ ATP $(10 \mathrm{mCi} / \mathrm{ml}$, PerkinElmer, Boston, MA). Binding reactions containing $0.035 \mathrm{pmol} / \mu \mathrm{l}$ of oligonucleotide and $8 \mu \mathrm{g}$ of nuclear protein were conducted at room temperature for $30 \mathrm{~min}$ in binding buffer $(10 \mathrm{mM}$ Tris$\mathrm{HCl}$, pH 7.5, $50 \mathrm{mM} \mathrm{NaCl}, 1 \mathrm{mM} \mathrm{MgCl}, 0.5 \mathrm{mM}$ EDTA, $0.5 \mathrm{mM}$ DTT, $4 \%$ glycerol $(\mathrm{v} / \mathrm{v})$, and $0.5 \mu \mathrm{g}$ poly $(\mathrm{dI}-\mathrm{dC})$ (Pharmacia, Peapack, NJ). The samples were loaded onto a $4 \%$ polyacrylamide gel, transferred to Whatman paper, and visualized by autoradiography. The experiments were carried out at least three times, and representative results are demonstrated in Figures.

\section{RT-PCR}

Gene expression of EGFR, HER2, and ER $\alpha$ was examined by RT-PCR and normalized to expression of GAPDH. Briefly, total RNA was extracted from untreated or bortezomib-treated RPMI8226 cells using RNeasy Kit and RNase-Free DNase Set (Qiagen, Valencia, CA). cDNA was synthesized using first strand cDNA synthesis Kit (SuperArray Bioscience, Frederick, MD). Gene-specific oligonucleotide primers (Invitrogen, Carlsbad, CA) included: EGFR, forward 5'-AGGCACGAGTAACAAGCTCAC-3' and reverse 5'-ATGAGGACATAACCAGCCACC-3'; ER $\alpha$, forward 5'-CCCACTCAACAGCGTGTCTC-3' and reverse 5'CGTCGATTATCTGAATTTGGCCT-3'; HER2, forward 5'- TGACACCTAGCGGAGCGAT-3' and reverse 5'- GGGGGATGTGTTTTCCCTCAA-3'; as well as GAPDH, forward 5'-AATCCCATCACCATCTTCCA-3' and reverse 5'-TGGACTCCACGACGTACTCA-3'. The experiments were carried three times, and representative results are demonstrated in Figures.

\section{Transient transfection of HDAC6 siRNA}

MCF7 cells were transiently transfected with HDAC6 siRNA (ON-TARGETplus ${ }^{\circledR}$ human HDAC6, Dharmacon Inc., Lafayette, CO) using "Cell Line Nucleofecto $^{\mathrm{TM}}$ Kit V," according to manufacturer's (Amaxa Biosystems, Gaithersburg, MD) instructions.
Following transfection, MCF7 cells were subjected to Western blotting and MTT assay, in the presence or absence of bortezomib. The experiments were carried out at least three times, and representative results are demonstrated in Figures.

\section{MCF-7 xenograft murine model}

Female $\mathrm{NCr} n u / n u$ mice (Charles River Laboratories, Wilmington, MA) were subcutaneously (sc) implanted with 17ß-estradiol-sustained release pellets (0.18 $\mathrm{mg}, 60$ day release time, Innovative Research, Sarasota, FL). Mice were inoculated sc with $5 \times 10^{6} \mathrm{MCF}-$ 7 cells suspended in 30\% Matrigel (BD Biosciences, San Diego, CA). After 1 month of growth, mice with measurable tumors $\left(>50 \mathrm{~mm}^{3}\right)$ were assigned into cohorts receiving intraperitoneal WT161 daily $(80 \mathrm{mg} / \mathrm{kg})$ or into a control group receiving vehicle alone (10\% DMSO, 90\% PBS). Caliper measurements of the longest perpendicular tumor diameters were performed every alternate day to estimate the tumor volume, using the formula volume $=1 / 2$ $\mathrm{x} \mathrm{L} \mathrm{x} \mathrm{W}{ }^{2}$. Animals were sacrificed when tumors reached $2 \mathrm{~cm}$ or if the mice appeared moribund. For each animal, relative tumor volume was determined by normalizing data to the baseline tumor volume for that animal at the start of treatment. Statistical significance was determined by 2-way ANOVA analysis. All animal studies were performed under the auspices of IACUC approved protocols.

\section{Immunohistochemistry}

Immunohistochemistry (IHC) was performed as described previously [53]. The primary Abs (anti-ER, -EGFR, -HER2, -ac-tubulin, -TUNEL) were visualized with the corresponding biotinylated $\mathrm{Ab}$ coupled to streptavidin-peroxidase complex (Vector Laboratories, Burlingame, CA). All Abs, conditions, and reactivities were tested in positive control slides. Histological photo micrographs were taken using a Leica DM200 microscope (aperture HC PLANs 10X/22, objective lenses: N PLAN 100X/1.25 oil), and a SPOT Insight QE Model camera with SPOT Advanced acquisition software (Diagnostic Instruments, Sterling Heights, MI).

\section{Immunocytochemistry}

Immunocytochemistry (ICC) was carried out as described previously [4]. Briefly, MCF7 cells were treated with WT161 $(1 \mu \mathrm{M})$ in the presence $(20 \mathrm{nM})$ or absence of bortezomib for $24 \mathrm{~h}$. Cells were then fixed in cold absolute acetone and methanol for 10 minutes. After fixation, cells were washed in PBS and then blocked for 60 minutes with $5 \%$ fetal bovine serum in PBS. Slides were then 
incubated with anti-LC3 antibody (Cell Signaling) at $4^{\circ} \mathrm{C}$ for 24 hours, washed in PBS, incubated with goat antimouse IgG-fluorescein isothiocyanate for 1 hour at $4^{\circ} \mathrm{C}$, and analyzed using Nikon E800 fluorescence microscopy. Images were taken with objective lenses (N Plan 60x/1.25 oil), using a SPOT Insight QE model camera with SPOT Advanced acquisition software (Diagnostic Instruments Inc, Sterling Heights, MI). The experiments were carried out at least two times, and representative results are demonstrated in Figures.

\section{Statistical analysis}

Statistical significance of differences observed in drug-treated versus control cultures was determined using the Wilcoxon signed-ranks test. The minimal level of significance was $p<0.05$. The interaction between HDAC inhibitors and bortezomib was analyzed by isobologram analysis using the CalcuSyn software program (Biosoft, Ferguson, MO) to determine whether the combination was additive or synergistic; a combination index $(\mathrm{CI})<$ 1.0 indicates a synergistic cell growth inhibitory effect.

\section{Author contributions}

TH performed experiments and wrote manuscript. RM performed experiments and interpreted data. JQ interpreted data. NM performed experiments. TJ-C performed experiments. KCA and JEB designed experiments and interpreted data. KA interpreted data and wrote manuscript.

\section{CONFLICTS OF INTEREST}

K.C. Anderson is on the advisory board of Celgene, Gilead, Millennium and Bristol Myers Squibb; and is a scientific founder with financial interest in Acetylon, Oncopep and C4 Therapeutics. JB is a scientific founder with financial interest in Acetylon.

\section{GRANT SUPPORT}

This study is supported by National Institutes of Health (NIH) SPORE CA10070, P01 78378, and R01 CA50947 (KCA), R01 CA178264 (TH, KCA); the LeBow Family Fund to Cure Myeloma (KCA); American Cancer Society Clinical Research Professorship (KCA); and NIH K08CA128972 (JEB).

\section{REFERENCES}

1. Valenzuela-Fernandez A, Cabrero JR, Serrador JM, Sanchez-Madrid F. HDAC6: a key regulator of cytoskeleton, cell migration and cell-cell interactions.
Trends Cell Biol. 2008; 18: 291-297.

2. Hideshima T, Bradner JE, Wong J, Chauhan D, Richardson P, Schreiber SL, Anderson KC. Small-molecule inhibition of proteasome and aggresome function induces synergistic antitumor activity in multiple myeloma. Proc Natl Acad Sci U S A. 2005; 102: 8567-8572.

3. Santo L, Hideshima T, Kung AL, Tseng JC, Tamang D, Yang M, Jarpe M, van Duzer JH, Mazitschek R, Ogier WC, Cirstea D, Rodig S, Eda H, et al. Preclinical activity, pharmacodynamic, and pharmacokinetic properties of a selective HDAC6 inhibitor, ACY-1215, in combination with bortezomib in multiple myeloma. Blood. 2012; 119 : 2579-2589.

4. Hideshima T, Qi J, Paranal RM, Tang W, Greenberg E, West N, Colling ME, Estiu G, Mazitschek R, Perry JA, Ohguchi H, Cottini F, Mimura N, et al. Discovery of selective small-molecule HDAC6 inhibitor for overcoming proteasome inhibitor resistance in multiple myeloma. Proc Natl Acad Sci U S A. 2016; 113: 13162-13167.

5. Rey M, Irondelle M, Waharte F, Lizarraga F, Chavrier P. HDAC6 is required for invadopodia activity and invasion by breast tumor cells. Eur J Cell Biol. 2011; 90: 128-135.

6. Tien SC, Lee HH, Yang YC, Lin MH, Chen YJ, Chang ZF. The Shp2-induced epithelial disorganization defect is reversed by HDAC6 inhibition independent of Cdc42. Nat Commun. 2016; 7: 10420.

7. Medler TR, Craig JM, Fiorillo AA, Feeney YB, Harrell JC, Clevenger CV. HDAC6 Deacetylates HMGN2 to Regulate Stat5a Activity and Breast Cancer Growth. Mol Cancer Res. 2016; 14: 994-1008.

8. Zhang Z, Yamashita H, Toyama T, Sugiura H, Omoto Y, Ando Y, Mita K, Hamaguchi M, Hayashi S, Iwase H. HDAC6 expression is correlated with better survival in breast cancer. Clin Cancer Res. 2004; 10: 6962-69688.

9. Saji S, Kawakami M, Hayashi S, Yoshida N, Hirose M, Horiguchi S, Itoh A, Funata N, Schreiber SL, Yoshida M, Toi M. Significance of HDAC6 regulation via estrogen signaling for cell motility and prognosis in estrogen receptor-positive breast cancer. Oncogene. 2005; 24: 45314539.

10. Hideshima T, Richardson P, Chauhan D, Palombella V, Elliott P, Adams J, Anderson KC. The proteasome inhibitor PS-341 inhibits growth, induces apoptosis, and overcomes drug resistance in human multiple myeloma cells. Cancer Res. 2001; 61: 3071-3076.

11. Hideshima T, Mitsiades C, Akiyama M, Hayashi T, Chauhan D, Richardson P, Schlossman R, Podar K, Munshi NC, Mitsiades N, Anderson KC. Molecular mechanisms mediating antimyeloma activity of proteasome inhibitor PS-341. Blood. 2003; 101: 1530-1534.

12. Richardson PG, Sonneveld P, Schuster MW, Irwin D, Stadtmauer EA, Facon T, Harousseau JL, Ben-Yehuda D, Lonial S, Goldschmidt H, Reece D, San-Miguel JF, Blade J, et al. Bortezomib or high-dose dexamethasone for relapsed 
multiple myeloma. N Engl J Med. 2005; 352: 2487-2498.

13. San Miguel JF, Schlag R, Khuageva NK, Dimopoulos MA, Shpilberg O, Kropff M, Spicka I, Petrucci MT, Palumbo A, Samoilova OS, Dmoszynska A, Abdulkadyrov KM, Schots $\mathrm{R}$, et al. Bortezomib plus melphalan and prednisone for initial treatment of multiple myeloma. N Engl J Med. 2008; 359: 906-9017.

14. Hideshima T, Bradner JE, Wong J, Chauhan D, Richardson P, Schreiber SL, Anderson KC. Small molecule inhibition of proteasome and aggresome function induces synergistic anti-tumor activity in multiple myeloma. Proc Natl Acad Sci USA. 2005; 102: 8567-8572.

15. Mitsiades N, Mitsiades CS, Richardson PG, McMullan C, Poulaki V, Fanourakis G, Schlossman R, Chauhan D, Munshi NC, Hideshima T, Richon VM, Marks PA, Anderson KC. Molecular sequelae of histone deacetylase inhibition in human malignant B cells. Blood. 2003; 101: 4055-4062.

16. Catley L, Weisberg E, Kiziltepe T, Tai YT, Hideshima T, Neri P, Tassone P, Atadja P, Chauhan D, Munshi NC, Anderson KC. Aggresome induction by proteasome inhibitor bortezomib and alpha-tubulin hyperacetylation by tubulin deacetylase (TDAC) inhibitor LBH589 are synergistic in myeloma cells. Blood. 2006; 108: 3441-3449.

17. Yoshida T, Zhang Y, Rivera Rosado LA, Chen J, Khan T, Moon SY, Zhang B. Blockade of Rac1 activity induces G1 cell cycle arrest or apoptosis in breast cancer cells through downregulation of cyclin D1, survivin, and X-linked inhibitor of apoptosis protein. Mol Cancer Ther. 2010; 9: 1657-1668.

18. Stehlik C, de Martin R, Kumabashiri I, Schmid JA, Binder BR, Lipp J. Nuclear factor (NF)-kappaB-regulated $\mathrm{X}$-chromosome-linked iap gene expression protects endothelial cells from tumor necrosis factor alpha-induced apoptosis. J Exp Med. 1998; 188: 211-216.

19. Kamemura K, Ito A, Shimazu T, Matsuyama A, Maeda S, Yao TP, Horinouchi S, Khochbin S, Yoshida M. Effects of downregulated HDAC6 expression on the proliferation of lung cancer cells. Biochem Biophys Res Commun. 2008; 374: 84-89.

20. Gao YS, Hubbert CC, Yao TP. The microtubule-associated histone deacetylase 6 (HDAC6) regulates epidermal growth factor receptor (EGFR) endocytic trafficking and degradation. J Biol Chem. 2010; 285: 11219-11226.

21. Kovacs JJ, Murphy PJ, Gaillard S, Zhao X, Wu JT, Nicchitta CV, Yoshida M, Toft DO, Pratt WB, Yao TP. HDAC6 regulates Hsp90 acetylation and chaperonedependent activation of glucocorticoid receptor. Mol Cell. 2005; 18: 601-607.

22. Scroggins BT, Robzyk K, Wang D, Marcu MG, Tsutsumi S, Beebe K, Cotter RJ, Felts S, Toft D, Karnitz L, Rosen $\mathrm{N}$, Neckers L. An acetylation site in the middle domain of Hsp90 regulates chaperone function. Mol Cell. 2007; 25: 151-159.
23. Lai CJ, Bao R, Tao X, Wang J, Atoyan R, Qu H, Wang DG, Yin L, Samson M, Forrester J, Zifcak B, Xu GX, DellaRocca S, et al. CUDC-101, a multitargeted inhibitor of histone deacetylase, epidermal growth factor receptor, and human epidermal growth factor receptor 2, exerts potent anticancer activity. Cancer Res. 2010; 70: 3647-3656.

24. He YY, Huang JL, Chignell CF. Cleavage of epidermal growth factor receptor by caspase during apoptosis is independent of its internalization. Oncogene. 2006; 25: 1521-1531.

25. Kawaguchi Y, Kovacs JJ, McLaurin A, Vance JM, Ito A, Yao TP. The deacetylase HDAC6 regulates aggresome formation and cell viability in response to misfolded protein stress. Cell. 2003; 115: 727-738.

26. Hideshima T, Bradner JE, Chauhan D, Anderson KC. Intracellular protein degradation and its therapeutic implications. Clin Cancer Res. 2005; 11: 8530-8533.

27. Mimura N, Fulciniti M, Gorgun G, Tai YT, Cirstea D, Santo L, Hu Y, Fabre C, Minami J, Ohguchi H, Kiziltepe T, Ikeda H, Kawano Y, et al. Blood. 2012; 119: 5772-5781.

28. Ramalingam SS, Maitland ML, Frankel P, Argiris AE, Koczywas M, Gitlitz B, Thomas S, Espinoza-Delgado I, Vokes EE, Gandara DR, Belani CP. Carboplatin and Paclitaxel in combination with either vorinostat or placebo for first-line therapy of advanced non-small-cell lung cancer. J Clin Oncol. 2010; 28: 56-62.

29. Kirschbaum MH, Goldman BH, Zain JM, Cook JR, Rimsza LM, Forman SJ, Fisher RI. A phase 2 study of vorinostat for treatment of relapsed or refractory Hodgkin lymphoma: Southwest Oncology Group Study S0517. Leuk Lymphoma. 2012; 53: 259-262.

30. Ellis L, Pan Y, Smyth GK, George DJ, McCormack C, Williams-Truax R, Mita M, Beck J, Burris H, Ryan G, Atadja P, Butterfoss D, Dugan M, et al. Histone deacetylase inhibitor panobinostat induces clinical responses with associated alterations in gene expression profiles in cutaneous T-cell lymphoma. Clin Cancer Res. 2008; 14: 4500-4510.

31. Haggarty SJ, Koeller KM, Wong JC, Grozinger CM, Schreiber SL. Domain-selective small-molecule inhibitor of histone deacetylase 6 (HDAC6)-mediated tubulin deacetylation. Proc Natl Acad Sci U S A. 2003; 100: 43894394.

32. Duong V, Bret C, Altucci L, Mai A, Duraffourd C, Loubersac J, Harmand PO, Bonnet S, Valente S, Maudelonde T, Cavailles V, Boulle N. Specific activity of class II histone deacetylases in human breast cancer cells. Mol Cancer Res. 2008; 6: 1908-1919.

33. Azuma K, Urano T, Horie-Inoue K, Hayashi S, Sakai R, Ouchi Y, Inoue S. Association of estrogen receptor alpha and histone deacetylase 6 causes rapid deacetylation of tubulin in breast cancer cells. Cancer Res. 2009; 69: 29352940.

34. Lima RT, Martins LM, Guimaraes JE, Sambade C, 
Vasconcelos MH. Specific downregulation of bcl-2 and xIAP by RNAi enhances the effects of chemotherapeutic agents in MCF-7 human breast cancer cells. Cancer Gene Ther. 2004; 11: 309-316.

35. Hong SW, Kim CJ, Park WS, Shin JS, Lee SD, Ko SG, Jung SI, Park IC, An SK, Lee WK, Lee WJ, Jin DH, Lee MS. p34SEI-1 inhibits apoptosis through the stabilization of the X-linked inhibitor of apoptosis protein: p34SEI-1 as a novel target for anti-breast cancer strategies. Cancer Res. 2009; 69: 741-746.

36. Chai J, Shiozaki E, Srinivasula SM, Wu Q, Datta P, Alnemri ES, Shi Y. Structural basis of caspase-7 inhibition by XIAP. Cell. 2001; 104: 769-780.

37. Kashkar H, Deggerich A, Seeger JM, Yazdanpanah B, Wiegmann K, Haubert D, Pongratz C, Kronke M. NF-kappaB-independent down-regulation of XIAP by bortezomib sensitizes HL B cells against cytotoxic drugs. Blood. 2007; 109: 3982-3988.

38. Zhuang S, Ouedraogo GD, Kochevar IE. Downregulation of epidermal growth factor receptor signaling by singlet oxygen through activation of caspase- 3 and protein phosphatases. Oncogene. 2003; 22: 4413-4424.

39. Alao JP, Lam EW, Ali S, Buluwela L, Bordogna W, Lockey P, Varshochi R, Stavropoulou AV, Coombes RC, Vigushin DM. Histone deacetylase inhibitor trichostatin A represses estrogen receptor alpha-dependent transcription and promotes proteasomal degradation of cyclin D1 in human breast carcinoma cell lines. Clin Cancer Res. 2004; 10: 8094-8104.

40. Yi X, Wei W, Wang SY, Du ZY, Xu YJ, Yu XD. Histone deacetylase inhibitor SAHA induces ERalpha degradation in breast cancer MCF-7 cells by CHIP-mediated ubiquitin pathway and inhibits survival signaling. Biochem Pharmacol. 2008; 75: 1697-1705.

41. Bali P, Pranpat M, Bradner J, Balasis M, Fiskus W, Guo F, Rocha K, Kumaraswamy S, Boyapalle S, Atadja P, Seto E, Bhalla K. Inhibiition of histone deacetylase 6 acetylates and disrupts the chaperone function of heat shock protein 90: A novel basis of antileukemia activity of histone deacetylase inhibitors. J Biol Chem. 2005; 280: 26729-26734.

42. Bennett EJ, Bence NF, Jayakumar R, Kopito RR. Global impairment of the ubiquitin-proteasome system by nuclear or cytoplasmic protein aggregates precedes inclusion body formation. Mol Cell. 2005; 17: 351-365.

43. Miller CP, Ban K, Dujka ME, McConkey DJ, Munsell M, Palladino M, Chandra J. NPI-0052, a novel proteasome inhibitor, induces caspase- 8 and ROS-dependent apoptosis alone and in combination with HDAC inhibitors in leukemia cells. Blood. 2007; 110: 267-277.

44. Lin Z, Bazzaro M, Wang MC, Chan KC, Peng S, Roden RB. Combination of proteasome and HDAC inhibitors for uterine cervical cancer treatment. Clin Cancer Res. 2009; 15: 570-577.
45. Jagannath S, Dimopoulos MA, Lonial S. Combined proteasome and histone deacetylase inhibition: A promising synergy for patients with relapsed/refractory multiple myeloma. Leuk Res. 2010; 34: 1111-1118.

46. Yee AJ, Bensinger WI, Supko JG, Voorhees PM, Berdeja JG, Richardson PG, Libby EN, Wallace EE, Birrer NE, Burke JN, Tamang DL, Yang M, Jones SS, et al. Ricolinostat plus lenalidomide, and dexamethasone in relapsed or refractory multiple myeloma: a multicentre phase 1b trial. Lancet Oncol. 2016; 17: 1569-1578.

47. Vogl DT, Raje NS, Jagannath S, Richardson PG, Hari P, Orlowski RZ, Supko JG, Tamang D, Yang M, Jones SS, Wheeler C, Markelewicz RJ, Lonial S. Ricolinostat, the first selective histone deacetylase 6 inhibitor, in combination with bortezomib and dexamethasone for relapsed or refractory multiple myeloma. Clin Cancer Res. 2017; 23:3307-3315.

48. Dasmahapatra G, Lembersky D, Kramer L, Fisher RI, Friedberg J, Dent P, Grant S. The pan-HDAC inhibitor vorinostat potentiates the activity of the proteasome inhibitor carfilzomib in human DLBCL cells in vitro and in vivo. Blood. 2010; 115: 4478-4487.

49. Chauhan D, Li G, Shringarpure R, Podar K, Ohtake Y, Hideshima T, Anderson KC. Blockade of Hsp27 overcomes Bortezomib/proteasome inhibitor PS-341 resistance in lymphoma cells. Cancer Res. 2003; 63: 6174-6177.

50. Hansen RK, Parra I, Lemieux P, Oesterreich S, Hilsenbeck SG, Fuqua SA. Hsp27 overexpression inhibits doxorubicininduced apoptosis in human breast cancer cells. Breast Cancer Res Treat. 1999; 56: 187-196.

51. Razandi M, Pedram A, Levin ER. Heat shock protein 27 is required for sex steroid receptor trafficking to and functioning at the plasma membrane. Mol Cell Biol. 2010; 30: 3249-3261.

52. Powers GL, Ellison-Zelski SJ, Casa AJ, Lee AV, Alarid ET. Proteasome inhibition represses ERalpha gene expression in ER+ cells: a new link between proteasome activity and estrogen signaling in breast cancer. Oncogene. 2010; 29: 1509-1518.

53. Hideshima T, Mitsiades C, Ikeda H, Chauhan D, Raje N, Gorgun G, Hideshima H, Munshi NC, Richardson PG, Carrasco DR, Anderson KC. A proto-oncogene BCL6 is upregulated in the bone marrow microenvironment in multiple myeloma cells. Blood. 2010; 115: 3772-3775.

54. Hideshima T, Chauhan D, Kiziltepe T, Ikeda H, Okawa Y, Podar K, Raje N, Protopopov A, Munshi NC, Richardson PG, Carrasco RD, Anderson KC. Biologic sequelae of IкB kinase (IKK) inhibition in multiple myeloma: therapeutic implications. Blood. 2009; 113: 5228-5236. 